\title{
Mass Media in Perspective of Parents Preschoolers in Kendari
}

\author{
Sitti Rahmaniar Abubakar ${ }^{a}$, Irawaty ${ }^{a}$, Nanang Sahriana ${ }^{b}$ \\ ${ }^{a}$ Early Childhood Teacher Education, Faculty of Education, Halu Oleo University, Kendari, Indonesia \\ ${ }^{\mathrm{b}}$ Universitas Negeri Semarang, Semarang, Indonesia \\ e-mail: sitirahmaniar@ymail.com
}

\begin{abstract}
This study aims to: 1) know the types of mass media accessed by preschoolers, 2) to know the behavioral development of preschool children, 3) to know the attitude of parents to the mass media for the development of preschool behavior. This research was conducted in Kendari of Southeast Sulawesi. This study used a case study method, respondents are parents who have preschool children who are considered in accordance of 10 people. Data were obtained with structured interview techniques in the elderly and observation in their children with age range of 4-6 years. The results showed that: 1) the mass media that is more often accessed by preschoolers is television. Television broadcasting with children's movies is the most watched, the next is the soap opera with teenage themes also become a spectacle of children, 2) the behavior of preschoolers based on the results of the study did not show deviant symptoms, 3) parents who have preschool children show the attitude positive. The conclusion is that parents' perceptions of the mass media are showing relatively good circumstances, showing no exaggerated anxiety about their impact on the development of their child's behavior. Suggestion is that parents together with the surrounding community to always control the spectacle of their children, perform mentoring, limit the time/hours watching television, and educate children about the adverse effects of addiction to watch, as well as institutions that serve to control the broadcasting of the media mass to further improve its performance.
\end{abstract}

Keywords: mass media, parent perception, child behavior, preschool age

\section{INTRODUCTION}

The development of modern technology greatly affects the life of mankind (Rahmad Wasdadi Julian, 2012). Along its development, the people of Indonesia began to recognize the internet, television, radio, smartphones and others. One of them is television which is an electronic mass media capable of spreading the news quickly and have the ability to access information and reach audiences in infinity at the same time. According to Effendy (2002: 21) the definition of television is broadcast television which is a medium of communication network with the characteristics of mass communication, which is one-way, communicator is institutionalized, the message is general, the target is to make the appearance, and the communication is heterogeneous.
The television with its various shows has been able to attract viewers, and makes its viewers 'addictive' to always watch the shows being aired. Even for children though it is an integral part of daily activity. Children can spend hours on end to watch their favorite television. The show "watch $T V^{\prime \prime}$ has become a mandatory agenda for them.

Today, it's hard to imagine a world without global media like TV or the Internet that most of us use every day. Children do the same. Most of them use the media every day, both at home and at school (Matyjas, 2015).

With shows ranging from infotainment, entertainment, advertising, to sinetrons and violent films, television is able to anesthetize its viewers (children, teenagers and parents) to continue watching events that are packed in such a way and spiked with interesting accessories, which makes the 
audience fascinated with the show presented. Not infrequently now many children prefer to linger in front of the television rather than learning, even almost forgetting the time to eat. This is a problem that occurs in our environment today and need special attention for every parent to always supervise the activities of children.

No doubt, with the mass media television is a lot of benefits that we can take. Where we will quickly obtain the latest information that happens anywhere and from any part of the world. So that we gain a broad insight and will not miss the hottest news of the present, we can know what are the problems that are going on. As a global human being must be able to criticize from any aspect of either social, economic, political, legal, and cultural.

If we examine further, actually the mass media of television has the main function that must be considered is the function of informative, educational, recreational and as a means of disseminating values or understandings (Effendi, 2002). However, when viewed today, television shows are more about functions informative and recreational only. While the function educational is a very important function to be submitted or informed is still very little.

This can be seen from the arrangement of television shows, mostly just the soap opera events are rife in various channels television. In addition infotaintment events that make the audience obsessed with gossip-gossip artists. While the events that lead to educational or small education once the frequency.

As an audio-visual media, TV is able to seize some channels of entry of messages or information into the human soul that is through the eyes and ears. $\mathrm{TV}$ is able to make people generally remember from what they see and hear on the television screen even once only aired.

Thus, especially for children in general always imitate what they see, does not rule out the behavior and attitude of the child will follow the television show that he watched. The results show that there is a habitual relationship of watching violence on television with aggressive behavior in preschoolers (Syarief \& dkk, 2013). If what he is watching is a more educative event, then it can have a positive impact but if he watches more on things that have no meaning even containing negative elements or deviations even to violence, then this will have an impact negative also to the behavior of children who watch the television show.

\subsection{Definition and Functioning of Mass Media}

Media is a tool or means used to convey messages from communicators to audiences, while understanding the mass media itself tools used in delivering messages from sources to audiences using communication tools such as newspapers, films, radio and television (Cangara, 2010: 123,126).

Low-income societies have a higher dependency and need for mass media than higheconomic people because of their limited choices. Higher-income societies have more choice and access to mass media, including direct inquire from sources or experts rather than relying on the information they get from certain mass media.

According Effendy (2006: 50), Mass communication is the spread of messages by using media aimed at the abstract mass, ie a number of people who are not visible to the message delivery. Readers of newspapers, radio listeners, television audiences and movies, are not visible to communicators.

Thus, that mass communication or communication through mass media is "one way" (one way traffic). The message is spread by the communicator, it is not known whether the message was received, understood, or performed by the communicant. The function of mass communication is to broadcast information (to inform), educate (to educate) and entertaining (to entertain). The main function of television is entertaining. Television presented in information and education, is only a complement to fulfill the natural needs of human beings.

According to Ruedi Hofmann (1999: 54-58), "The other five functions of television are, among other things, the surveillance of the situation of society and the world, connecting with each other, channeling culture, entertainment and mobilizing society to act in an emergency." In Theory of Usefulness and Advantages that television viewers are more active than is generally suspected. Television can directly mobilize the community with a specific purpose. Instead, the television is used by viewers.

\subsection{Negative Impacts of Television}

Not to mention entering the reading culture, Indonesia has been forced and turned to oral and culturevisual culture. This can be seen from the 
dominance of television in Indonesia and the low interest in reading the community. Today most people in Indonesia spend their spare time watching television.

According to Effendy (1986: 122), the influence of television cannot be separated from the influence on aspects of life in general. That television has an effect on the life of Indonesian society, already many know and feel it, either positive or negative influence. Television shows generally affect the attitude, perception, and feelings of the audience. So that the audience touched, fascinated, or talkative. Because one of the psychological effects of television as if to hypnotize the audience so that they seemed to drift in the involvement of stories or events presented television. Everyone will be happy to watch their favorite shows on television ".

The influence of media on children is getting bigger, the technology is getting more sophisticated and the intensity is higher. The rapid development of the digital industry has become a formidable challenge for education and parents in preparing students to deal with the "flood of information" brought by the media. Though parents have enough time to pay attention, accompany and supervise the child. Children spend more time watching TV than doing other activities.

The negative impact of television shows is greater than the positive impact on child development. From television, children can watch all the shows including those not yet worth watching, ranging from violence and sex life. Negative impacts on television shows include:

a) influencing the development of the brain, b) the decline or loss of interest in reading and motivation of the child so that the child does not have the spirit of learning, c) changes in behavior on the character and mentality, d) make the child becomes consumptive because ad impressions offer a variety of products, e) enticing and addictive so that children become lazy to learn, f) reduce creativity, lack of play and socialize into individual and individual humans, g) increased aggressiveness and criminality, and $\mathrm{h}$ ) too often watching television and never read cause the child will have a simple, less critical, linear or unidirectional pattern of thought and will ultimately affect his or her imagination, intellect, and cognitive development.

Television broadcasts have poisoned the brains of children with a variety of inappropriate shows to their spectacle. Children have not been able to discern what is good and what is bad and what is inappropriate and inappropriate. They just know that television is good, they feel happy and entertained and feel curious to keep on following the event for the next event. Television media has a very strong imitative power for the growth and development of children. This negative impact is the concern of parents to limit the time watching television, watching and selecting impressions that are worth watching by children.

\subsection{Role of Parents in Overcoming Negative Impacts of Television for Children}

Family education as the basis for the formation of the child's personality. The role of father and mother is crucial for the development factor of the child's personality. Those in charge of the whole family. It is they who determine the conditions of child development, where the family will be taken, what colors are given to the family. Children before they can take responsibility themselves, still very dependent parents.

Parents have a very important role, the character and personality of children affected by the environment, especially from parents. Every parent has the responsibility to always keep an eye on the child and pay attention to the progress. Therefore the smallest things should be anticipated by each parent about the positive and negative impact that will be generated. Actually, a lot of the impact caused by television viewing. Some things parents do are:

1. Choose an event that is appropriate for the age of the child.

2. Accompany children watching TV.

3. Take advantage of the little time as well as a means of learning children.

4. Take the children out to enjoy nature and the environment, socialize and be positive with others.

5. Increasing reading books and putting books in a place that is easy to reach children.

6. Multiply listening to the radio, playing the tapes or listening to music instead of watching television.

\section{METHOD}

This research was conducted in Kambu District Kendari, Southeast Sulawesi in January 2017. The research type is qualitative with case study method, which produce descriptive data in the form of words 
from people and observed behavior so as to produce a report.

Research respondents are parents who have preschool children in Kambu who are considered in accordance with the criteria of 10 people. Data were obtained with structured interview techniques in the elderly and observation in their children aged between 4 to 6 years.

\section{RESEARCH}

Television is one form of technology that can provide solutions to meet the demands of the present era, which when compared with other media television has several advantages such as mastering space and distance and has a wide range (Pramadiansyah, 2014).

Family education as the basis for the formation of child's personality and behavior. The role of father and mother is crucial for the development factor of the child's personality. Those in charge of the whole family. It is they who determine the conditions of child development, where the family will be taken, what colors are given to the family. Children before they can take responsibility for themselves, still rely heavily on their parents.

The results showed that: 1) mass media more often accessed by preschool children in Kambu is television. Television broadcasting with children's movies is the most watched, next is the soap operas with teenage themes also participated in preschool show, 2) the behavior of preschool children in Kambu based on the results of the study did not show deviant symptoms, 3) parents who have children aged preschool in Kambu shows a positive attitude.

\section{DISCUSSIONS}

mass media that are more frequently accessed by preschoolers in Kambu are television. Television broadcasts with children's movies are the most watched, the next is a soap opera with teenage themes also participated to be a showcase of preschoolers.

Not All television programs are bad for children. There are also impressions that have a good side, such as educational events. Much information can be absorbed from television that is not available from anywhere else. However, on the other hand there are also many television shows that can be bad for children. The results concluded, as a visual audio media, television is able to seize 94 percent of the channel entry of messages or information into the human soul that is through the eyes and ears. TV is able to make people generally remember 50 percent of what they see and hear on screen, even if only once aired. In children who generally always imitate what they see, it is possible that their behavior and attitudes will mimic the violence shown on television they watch (Kartila, 2012).

This is in line with the results of research conducted by Yanti et al. (2016) that the impact of children watching TV is doing two types of violence, namely physical and verbal violence; television shows that children often see is a cartoon animated film that contains elements of violence.

The behavior of preschool children in Kambu based on the results of the study did not show any deviant symptoms. This is in line with the research ever conducted Desti (2005) concluded that the many assumptions that the television media is the cause of violence and rape is less precise. Admittedly the bad side of television, but this media can also be a useful companion in providing knowledge and skills, and useful entertainment.

Another opinion says that the perception of parents to gadgets is not only a technology tool but also a negative impact (De Lima \& Castronuevo, 2016). Supported by Novitasari \& Khotimah (2016) that the use of gadgets affects the social interaction of children aged 5-6 years. Many of the negative impacts that will arise include: will be difficult to socialize, slow in motor development, and significant behavioral changes. So it is very important role of parents to supervise, control and pay attention to all activities of children (Chusna, 2017).

Parents who have preschool children in Kambu District show a positive attitude towards the use of television media this is because the children are not addicted to the media. In addition, parents control and ensure that children do not exceed the time limit set in watching TV.

\section{CONCLUSION}

Thus, it can be stated that television is one of the media most often accessed / watched by preschoolers, which inevitably brings both negative and positive impacts. The role of parents is needed in this case as a protection against the spectacle that is not feasible for children. Parents with preschool 
children in Kambu show a positive attitude due to the strict supervision of parents so that children do not become addicted.

The suggestions presented are as follows: 1) every parent should detect the development of the main child for an early child, so that it can be known immediately if there is behavior irregularities to be done right handling, 2) parents together with the surrounding community in order to always control the spectacle of his children, perform mentoring, limit the time / hours of watching television, and educate children about the adverse effects of drug addiction, 3) The institution that serves to control the broadcasting of the mass media to further improve its performance 4) government, community leaders, and religious leaders should show a high level of concern for the development of the child's personality for the sake of a brilliant Indonesia generation.

\section{REFERENCES}

[1] Cangara, Hafied. 2010. Pengantar Ilmu Komunikasi. Jakarta: Rajawali Pers

[2] Chusna, P. A. (2017). Pengaruh Media Gadget Pada Perkembangan Karakter Anak. Dinamika Penelitian, 17(2), 315-330.

[3] De Lima, L., \& Castronuevo, E. (2016). Perception of parents on children's use of gadgets. The Bedan Journal of Psychology, II, 26-34.

[4] Desti, S. (2005). Dampak Tayangan Film Di Televisi Terhadap Perilaku Anak. Jurnal Komunikologi, 2(1), 1-7.
[5] Effendy, Onong Uchjana. 1986. Dinamika Komunikasi. Bandung: PT. Remaja Rosda Karya.

[6] Effendy, Onong Uchjana. 2002. Hubungan Masyarakat Suatu Studi Komunikologis. Bandung: PT. Remaja Rosdakarya.

[7] Effendy, Onong Uchjana. 2006. Ilmu Komunikasi: Teori dan Praktek. Bandung: PT. Remaja Rosda Karya.

[8] Kartila, I. (2012). Anak-anak Cenderung Meniru Adegan di Televisi - Kompas.com.

[9] Matyjas, Bożena. (2015). Mass media and children. Globality in everyday life. Procedia Social and Behavioral Sciences 2898-2904.

[10] Novitasari, W., \& Khotimah, N. (2016). Dampak Penggunaan Gadget Terhadap Interksi Sosial Anak Usia 5-6 Tahun. Jurnal PAUD Teratai, 5(3), 182-186.

[11]

[12] Rahmad Wasdadi Julian. (2012). Perkembangan teknologi modern.

[13] Ruedi, Hofmann. 1999. Dasar-dasar Apresiasi Program Televisi. Jakarta: PT Gramedia Widiasarana Indonesia.

[14] Pramadiansyah, Yudhi. 2014. Pengaruh Televisi terhadap Pembentukan Perilaku Kekerasan. Skripsi. Universitas Indonesia.

[15] Syarief, L., \& Dkk. (2013). Hubungan Kebiasaan Menonton Tayangan Kekerasan di Televisi dengan Perilaku Agresif pada Anak Pra Sekolah di TK Islam Terpadu Al Akhyar Kabupaten Kudus. Indonesia, Jurnal Keperawatan Anak Persatuan Perawat Nasional, 1, 91-98.

[16] Yanti, R., Ahmad, A., Maidiyah, E., (2016). Perkembangan Sosial Emosional Anak yang Menonton Film Animasi di TK Idaman Hati Kecamatan Sawang Aceh Utara. Jurnal Ilmiah Mahasiswa Pendidikan Anak Usia Dini, 1(1), 76-85. 